\title{
An Assessment of Proximate Composition, Antioxidant Activities and LC/MS Based Phytochemical Profiling of Some Lichen Species Collected From Western Ghats of Southern Part of India
}

\author{
Shenbagam Muthu ${ }^{1}$, Mariraj Murugan ${ }^{1}$, Kalidoss Rajendran ${ }^{1}$ and Ponmurugan \\ Ponnusamy, ${ }^{2, *}$
}

${ }^{1}$ Research Scholar, Biomedical Research Lab, Department of Botany, Bharathiar University, Coimbatore - 641 046, Tamil Nadu, India;

${ }^{2}$ Associate professor, Biomedical Research Lab, Department of Botany, Bharathiar University, Coimbatore - 641 046, Tamil Nadu, India.

Received: June 7, 2020; Revised: September 26, 2020; Accepted: Oct 13, 2020

\begin{abstract}
The lichen samples of Parmotrema tinctorum, Pseudocyphellaria aurata, Ramalina taitensis, Usnea bismolliuscula are being used as nutraceutical agents in indigenous system of medicine. The main objectives of this study were assessing the proximate composition in lichen samples of the extracts and their antioxidant properties. Using Liquid Chromatography Mass Spectrophotometric analysis with chemoprofiling of the studied lichen compositions were also done. The petroleum ether, acetone, methanol and water extracts of test samples obtained from Soxhlet apparatus were assessed for in vitro antioxidant activities using 1,1-diphenyl-2-picrylhydrazine, Superoxide anion radical, 2, 2'-Azino-Bis-3Ethylbenzothiazoline-6-Sulfonic Acid scavenging and Phosphomolybdenum reduction assays. The methanol extract of test samples revealed higher content of phytochemical constituents. The acetone extract of P. aurata showed strong DPPH radical scavenging activity with $\mathrm{IC}_{50}$ value of $93.339 \mu \mathrm{g} / \mathrm{mL}$. Similarly, the methanol extract of $U$. bismolliuscula and R.taitensis showed maximum ABTS scavenging potency and phosphomolybdenum reduction activity and with the highest values of $85.6 \pm 0.5 \mathrm{TE} / \mathrm{g}$ and $150.68 \pm 1.15 \mathrm{mg} \mathrm{AA} / \mathrm{g}$ respectively. LCMS analysis of lichen extracts exhibited the secondary metabolites containing atranorin, sekikaic acid and usnic acid. It is concluded that these lichen species might be a valuable nutraceutical agent. Thus, the lichen extracts may further be assessed to toxic assays on experimental animals to confirm their biological activities.
\end{abstract}

Keywords: Lichens, Nutritional, Phytochemicals, Antioxidants, LC/MS

\section{Introduction}

Lichens contain mycobiont that has a defensive role and photobiont that supplies food. They have historically been used as spices in food, dyes in textile, odorant in perfume industry (Kosanic et al., 2014). In our human body, singlet oxygen, hydroxyl $\left(\mathrm{OH}^{-}\right)$radicals, super oxide $\left(\mathrm{O}^{2-}\right)$ anions and hydrogen peroxide $\left(\mathrm{H}_{2} \mathrm{O}_{2}\right)$ are biological Reactive Oxygen species (ROS) that induce oxidative stress and trigger degenerative diseases such as cancer, premature aging, diabetes, metabolism disorders and heart disorders (Kosanić \& Ranković 2010). The lethal effect of radiation and pollutants and other exogenous factors are attributed to the formation of free radicals in biological systems. Lichen secondary metabolites such as depsides dibenzofuran-heterocyclic aromatic compound, depsidones-ester and pulvinic acid are all natural phenolic compounds were described to have antioxidant activities, and hence attracted considerable attention (Nguyen et al., 2019).

Proximate elements of carbohydrates, proteins, fats and antioxidant properties of secondary metabolites of phenols are naturally found in lichens. Synthetic agents mostly used as conventional chemical antioxidants have been pronounced to pose side effects such as inflammation and cell damage. Therefore, there has been the global interest in finding promising alternative antioxidant compound from natural sources. Conventionally, following solvents with different polarities such as petroleum ether, chloroform, acetone and methanol have commonly been employed to extract compounds from lichen thallus (Biney et al., 2020) which deliver the dissolved compounds to diffuse into the cell through membrane pores and help to trigger its action. They have the property of low viscosity and high diffusivity (Biney et al., 2020).

Although intensive and extensive assessment on the nutraceutical properties of most plants have been documented, little is known about the lichens in all over the World. Two such lichens include Parmotrema tinctorum and Pseudocyphellaria aurata, which are temperate foliose lichen. The relation of Parmotrema tinctorum with other spices in cooking is interesting and the use of this species may often add flavour in many dishes such as vegetables and meat by indigenous groups in Nepal and India (Upreti et al., 2005). Pseudocyphellaria aurata, also known as specklebelly, belonged to the family Lobariaceae, while members of genus Pamotrema called

\footnotetext{
* Corresponding author e-mail: ponmurugan@buc.edu.in.
} 
as "ruffle lichens" belonged to Parmeliaceae. The tea prepared from Pseudocyphellaria aurata is considered to be beneficial for the health, particularly for the intestinal tract in curing indigestion. This has been used in Madagascar. The Ramalina taitensis, used to synthesize chemical compounds such as tannins, alkaloids, and saponins that are for biological functions, including antioxidant role and defence against microbial agents (Chowdhery 2014). The lichen substances of Usnea bismolliuscula play a great role in inhibition of tyrosine activity in medicine (Rajeswari et al., 2019). Two of these species include which are fruticose lichens in the family Ramalinaceae and Parmeliaceae respectively. The members of the genus Usnea are called old man's beard lichens and Ramalina are called strap lichens. These lichens have shown many health beneficial properties, such as possessing antibiotic, antioxidant, antiviral, antitumour, anti-allergenic and anti-inflammatory properties (Shrestha \& St. Clair 2013). This has aroused further interest in the study of these lichens. Therefore, in the present study, the proximate chemicals, antioxidant property, and LC/MS analysis of methanol and acetonewater extracts of Parmotrema tinctorum, Pseudocyphellaria aurata, Ramalina taitensis, Usnea bismolliuscula were investigated to document the potential biological activities of these lichens. The results indicated that these lichen possess very high antioxidant potentiality, which gave immense scope for further exploration in nutritional and phytochemical studies.

\section{Materials and methods}

\subsection{Collection and identification of lichen samples}

Fresh thalli of Parmotrema tinctorum, Pseudocyphellaria aurata, Ramalina taitensis,

Usnea bismolliuscula were collected from Kodaikanal hills of Western Ghats, Southern India, during the winter season (January 2019). The elevation of hills was measured about 2130 meters. Identification of lichen was carried out at Biomedical Research lab, Bharathiar University, Coimbatore, Tamil Nadu, India. Voucher specimens were deposited at lichen herbarium centres, Bharathiar University, Coimbatore, India and CSIRNational botanical research Institute NBRI, Lucknow, India. The lichen specimens were identified by matching with the identification keys documented in Awasthi's identification key manual (Awasthi 2007). The species were chemically identified with the help of conventional spot tests (K, C, I, KC) (Orange et al., 2001). Lichen thalli were rinsed under flowing tap water to wash away soil particles. The samples were air-dried and left under sun shade to remove moisture. The air dried samples were blended into powder using a mixer and used for further analysis.

\subsection{Nutritional studies}

\subsubsection{Proximate chemical composition}

Standard procedure was followed for the proximate chemical composition analysis of phytochemicals such as proteins, carbohydrates, total phenolics, amino acids, and total flavonoids (Lowry \& Rosebrough 1951) lipids and fibre contents (AOAC 1990).

\subsubsection{Amino acids analysis}

Amino acid content in the lichen extract was quantified according to the procedure described by Mohapatra et al. (2019). Briefly, a known amount of $100 \mathrm{mg}$ of blended sample was acid treated with $10 \mathrm{~mL} 6 \mathrm{~N} \mathrm{HCl}$. The reaction mixture was digested in an oven at $120^{\circ} \mathrm{C}$ for 24 h. The aliquots were filtered out using the filter paper Whatman No. 1. The content was subjected to a vacuum flash evaporator. The amino acid concentrate was acid treated using $0.05 \mathrm{~N}$ Hydrochloric acid and filtered again using a $0.45 \mu \mathrm{M}$ membrane filter and a volume of $20 \mu \mathrm{L}$ was passed by injection into an amino acid analyzer (Shimadzu LC-10AS HPLC, McKinley Scientific, Sparta, NJ, USA) fitted with an ion exchange resin (styrene divinyl benzene co-polymer with sulphonic group) in column. The reference amino acid was injected to measure the amount of amino acid in the test sample. Amino acid standard was also run to calculate the concentration of amino acids in the samples.

\subsubsection{Mineral analysis by ICP-MS (Liu et al., 2020)}

During the last decades, ICP-MS (Inductively Coupled Plasma Mass Spectrometry) has emerged as the most promising technique for the analysis of trace elements of biological or environmental samples, and it is routinely used for the determination of up to eighteen elements in ionomic research studies. The mineral analysis of lichen samples was done by the ICP - MS instrument of (Nex Ion $300 \mathrm{X}$, Perkin Elmer, USA). The powdered lichen material (200mg) was digested at $80^{\circ} \mathrm{C}$ with $10 \mathrm{~mL}$ of tri-acid (Nitric acid, Sulphuric acid and per chloric acid, 9:2:1) This test was performed by following the method of Lie et al. (2020). After digestion, all the samples were made up to $100 \mathrm{~mL}$ and aspirated into ICP - MS (Nex Ion $300 \mathrm{X}$, Perkin Elmer, USA).

\subsection{Preparation of solvent extract}

The extraction of lichen sample was done using the Soxhlet apparatus. The powdered lichen samples were loaded in pockets of thimbles and introduced in the extractor. Then, extraction was done separately using 250 $\mathrm{mL}$ solvents in an increasing polarity such as petroleum ether, acetone, methanol and water and heated up to $80^{\circ} \mathrm{C}$ for $8 \mathrm{~h}$. Then, the extracts were concentrated using rotary vacuum evaporator (Superfit make, India). The concentrate thus obtained was weighed and stored in refrigeration at $4^{\circ} \mathrm{C}$. Three samples from each solvent extract were examined for phytochemical and biological activities to assess variations in the test analysis. The presence of different lichen substances in each extract justifies the use of different solvents in an increasing polarity for extraction.

\subsection{Quantitative analysis of phytochemicals.}

\subsubsection{Estimation of total phenolic content (TPC)}

The procedure is based on the method given by $\mathrm{Ng}$ and See (2019); Gaafar et al. (2019). Each sample was tested by adding $100 \mu \mathrm{L}$ of extract $(1 \mathrm{mg} / \mathrm{mL})$ in $500 \mu \mathrm{L}$ of $10 \%$ Folin-Ciocalteau reagent solution and incubating for $5 \mathrm{~min}$ at room temperature. This was followed by adding $2.5 \mathrm{~mL}$ of $7.5 \%$ sodium carbonate solution and incubating in dark for $45 \mathrm{~min}$. The colour changes in test tubes were measured in spectrophotometer at $760 \mathrm{~nm}$. The concentration ranges between $0-100 \mu \mathrm{g} / \mathrm{mL}$ of the 
suggested Gallic acid standard were analysed to obtain the calibration curve. The mean \pm standard deviation of readings was calculated, and the results of TPC were represented in milligrams of gallic acid equivalents $( \pm \mathrm{sd})$ per $g$ of the lichen extract.

\subsubsection{Estimation of total flavonoid content (TFC)}

The TFC procedure is based on Abdel-Mawgoud et al. (2019); Ng and See (2019) technique. About $500 \mu \mathrm{L}$ of the extracts were mixed with $300 \mu \mathrm{L}$ of $5 \%$ sodium nitrate solution followed by $300 \mu \mathrm{L}$ of $10 \%$ Aluminium chloride and incubated at room temperature. The content of the tube was added with $4 \%$ sodium hydroxide. As standard, a test tube containing Rutin was used to obtain calibration curve. From each extracts, triplicate samples were examined separately to find out any variations in the assessment of TFC and the mean value was calculated. The results were represented as Rutin Equivalents ( \pm sd).

\subsection{In vitro antioxidant assays}

\subsubsection{DPPH radical scavenging activity}

The 1,1-diphenyl-2-picrylhydrazine (DPPH) radical scavenging activity was determined bestowing to the procedure of Ng and Rosman (2019); Sedjati et al. (2020). Stable 1,1-diphenyl-2-picrylhydrazyl (DPPH) was assessed to examine the free radical capturing ability of $\mathrm{H}+$ ions. DPPH has the potency to donate $\mathrm{H}+$ ions to atoms that can give rise to free radicals of hydrogen. Reduction in the amount of DPPH molecule determines the free radical scavenging ability. It was analysed by detecting the absorbance readings at $570 \mathrm{~nm}$. Reading in the absorbance decreases as the free radicals scavenged by the active substances of the lichen extracts increases. The percentage of inhibition for lichen extract was compared with the commercial ascorbic acid standard. The reaction mixture contained $100 \mu \mathrm{L}$ of aliquots with different concentrations of extracts. The positive control has different concentrations of ascorbic acid standard added with $3.0 \mathrm{~mL}$ of DPPH solution. The mixture was left in dark for $30 \mathrm{~min}$ at room temperature. The absorbance of the sample was read at $517 \mathrm{~nm}$ against a blank (methanol). The average of three readings was calculated. The following formula determines the results of half the inhibition concentration value $\left(\mathrm{IC}_{50}\right)$ for $\mathrm{DPPH}$ radical scavenging ability of test samples:

$$
\mathrm{X}=\left[\left(\mathrm{A}_{0}-\mathrm{A}_{1}\right) / \mathrm{A}_{0}\right] \mathrm{x} 100
$$

Where $\mathrm{X}=\%$ Inhibition, $\mathrm{A}_{0}$ is the absorbance of the control and $\mathrm{A}_{1}$ is the absorbance of the sample extracts/standard.

\subsubsection{Superoxide anion radical scavenging activity}

The principle of this assay is based on the ability of lichen extracts to inhibit the formation of formazan by scavenging the superoxide radicals present in riboflavinlight-NBT system according to the procedure described by (Thangaraj, 2016). About $3 \mathrm{~mL}$ reaction mixture contained $50 \mathrm{mM}$ Sodium phosphate buffer $\mathrm{pH}$ (7.6), riboflavin $20 \mu \mathrm{g}$, EDTA (12mM), NBT (0.1 mg) and $100 \mu \mathrm{L}$ sample of lichen extract. The absorbance of the sample was measured at $590 \mathrm{~nm}$ against a blank (methanol). The mean value of triplicate readings was recorded. The percentage of half the inhibition concentration value $\left(\mathrm{IC}_{50}\right)$ of superoxide anion generation was calculated by following equation:

$$
X=\left[\left(A_{0}-A_{1}\right) / A_{0}\right] \times 100
$$

Where $\mathrm{X}=$ Superoxide anion scavenging activity, $\mathrm{A}_{0}$ is the absorbance of the control and $A_{1}$ is the absorbance of the sample extracts/standard

\subsubsection{ABTS $^{+}$(2, 2'-Azino-Bis-3-Ethylbenzothiazoline-6- Sulfonic Acid) radical scavenging activity}

The principle of ABTS scavenging assay is based on the ability of lichen extract to reduce ABTS and lead to the decolouration of a green color complex to colourless. About $1 \mathrm{~mL}$ of diluted ABTS solution was transferred to the tube containing an aliquot of lichen extract (Rutin as standard) followed by adding $2.4 \mathrm{mM}$ of potassium per sulphate and left in the dark. Triplicate determinations were calculated and the results of ABTS scavenging activity were read at $734 \mathrm{~nm}$ against a blank ethanol. The result was represented in $\mathrm{mM}$ of Trolox equivalents per $\mathrm{g}$ of the lichen extract (Makawy et al., 2019).

\subsubsection{Phosphomolybdenum reduction assay}

The antioxidant potency of the lichen extracts was assessed by the phosphomolybdenum reduction assay (Zengin et al., 2015). The assay was based on the ability of a substance in lichen extract to reduce phosphomolybdic acid to blue complex phosphomolybdenum. A reagent solution was prepared containing ammonium molybdate (4 $\mathrm{mM} / \mathrm{L})$ and sodium phosphate $(0.6 \mathrm{mM} / \mathrm{L})$. Exactly, $250 \mu \mathrm{l}$ of the extracts was added with $3 \mathrm{~mL}$ of the reagent solution. The tubes with reaction mixture were incubated at $95^{\circ} \mathrm{C}$ for $90 \mathrm{~min}$. The absorbance of the reaction mixture was measured at $695 \mathrm{~nm}$ using spectrophotometer against blank (0.3 mL methanol and $3 \mathrm{~mL}$ reagent). The ascorbic acid was used as standard $(1 \mathrm{mmol} / \mathrm{L}$ ascorbic acid in DMSO). The assay was done in triplicates.

\subsection{Liquid Chromatography coupled to Mass Spectrometry (LC/MS) analysis}

For studying LC/MS method followed by Zhang et al. (2019), the lichen substances obtained from the methanol extract of lichen samples were identified using Linear Trap Mass Spectrometer (Thermo Scientific). The extracts containing $5 \mu$ l were injected into a UPLC(R)BEH C18 $1.7 \mu \mathrm{m}-(2.1 \times 100 \mathrm{~mm}))$ on a Water Xevo TQD 2000 C18 column which consists of 3000 nano system. The flow rate was followed at an interval of time $0.3 \mathrm{ml} / \mathrm{min}$ with the gradient elution program. The solvent mixture containing 70\%-Acetonitrile : $30 \%$ Formic acid in water served as mobile phase and total run over time was automated to flow in $10.0 \mathrm{~min}$. The compounds were identified using peaks and collected by scanning at wide wavelengths ranges between 100 and 1000 atomic mass units over the mass/charge number $(\mathrm{m} / \mathrm{z}$ ) (Xcalibur version 4.0). The LC/MS profile of the prevailing lichen compounds were compared with the standard Chemindex lichen data base. The mass spectral data for each compound was standardized to ensure the most favourable ion transfer conditions, ionization and obtained optimum peak of both the precursor and fragment ions. The source peak was compared for its identity for all the lichen samples.

\subsection{Statistical analysis}

All tests were prepared in triplicates. Data are documented as mean \pm standard error. The result was analysed statistically. The SPSS version 20.0 was used for this purpose. The one way ANOVA approach by Duncan's 
test was followed. Mean values at $\mathrm{p}<0.05$ were found statistically significant. For the graphical representation, $\mathrm{R}$ software version 3.5.1 was employed.

\section{Results}

\subsection{Proximate composition of samples.}

\subsubsection{Moisture and ash contents of samples.}

The moisture and ash contents of $P$. tinctorum, $P$. aurata, R.taiensis and $U$. bismolliuscula were investigated and results are presented in Table 1 . The availability of moisture content was found to be significant in lichen extract at any stage of nutritive analysis. The lichen moisture content was carried out in triplicates. It was found that the $P$. aurata showed lichen with lowest moisture content (9.3\%) as compared to other lichen extracts. The $U$. bimolliuscula showed moderate moisture content $(9.8 \%)$. The result findings of $P$. tinctorum showed maximum moisture content of $10.5 \%$ followed by $R$. taitensis with $10 \%$. Similarly, the ash content was calculated and the results indicated positive effect with the lichens. Parmotrema tinctorum extracts were compared with the values of other lichen samples which showed highest level of total ash content which was up to $13.93 \%$.

Table 1. Proximate chemical composition of Lichen samples

\begin{tabular}{llllll}
\hline Parameters & $\begin{array}{l}\text { Total carbohydrates } \\
\text { (mg glucose } \\
\text { equivalents/g sample) }\end{array}$ & $\begin{array}{l}\text { Total proteins } \\
\text { (mg BSA } \\
\text { equivalents/g } \\
\text { sample) }\end{array}$ & $\begin{array}{l}\text { Total starch } \\
\text { (mg glucose } \\
\text { equivalents/g } \\
\text { sample) }\end{array}$ & $\begin{array}{l}\text { Energy } \\
\text { (\%) }\end{array}$ & $\begin{array}{l}\text { Moisture } \\
\text { content (\%) } \\
\text { content } \\
\text { (\%) }\end{array}$ \\
\hline P. tinctorum & $64.6 \pm 0.01$ & $25.78 \pm 0.03$ & $0.17 \pm 0.03$ & 82.85 & 10.5 \\
P. aurata & $31.63 \pm 0.3$ & $11.65 \pm 0.11$ & $0.14 \pm 0.09$ & 54.75 & 9.3 \\
R. taitensisn & $50.12 \pm 0.1$ & $14.10 \pm 0.5$ & $0.12 \pm 0.06$ & 74.89 & 10 \\
U. bimolliuscula & $58.52 \pm 0.02$ & $24.95 \pm 0.03$ & $0.13 \pm 0.05$ & 60.05 & 9.8 \\
\hline
\end{tabular}

\subsubsection{Determination of nutrient contents}

The proximal composition of the lichen extracts such as P. tinctorum, P.aurata, R. taiensis and U. bismolliuscula are shown in Table 1 . The total carbohydrates content was found highest in $P$. tinctorum $(64.6 \pm 0.01 \mathrm{mg} \mathrm{GE} / \mathrm{g}$ sample), whereas $P$. aurata (31.6.3 $\pm 0.3 \mathrm{mg} \mathrm{GE} / \mathrm{g}$ sample) registered lower carbohydrate content. The $P$. tinctorum had a maximal amount of total protein content (25.78 $\pm 0.03 \mathrm{mg}$ BSAE/g sample) when compared to other lichens. Moreover, the lichen species, $R$. taiensis exhibited highest starch content. The $P$. tinctorum yielded a high energy level (82.85\%) in the analyzed lichen extracts. The differences between the activity of standard used in each antioxidant assay was compared with previous published papers. Comparison of standard values with previous paper's standard values for the same assay validated moisture content results in this study. The present study has shown that the protein content of lichens is considerably low (foliose $1.87 \%$ and fruticose $1.9 \%$ ) compared to the protein content of $P$. pseudotinctorum (16.2\%) (Vinayaka et al., 2010).

\subsubsection{Mineral composition of lichen samples}

Mineral composition of the $P$. tinctorum, $P$. aurata $R$. taiensis and $U$. bismolliuscula were analysed and presented in Table 2. Among all minerals tested, calcium was found to be the highest in all lichen extracts followed by potassium. The third highest element was magnesium in $R$. taitensis (710 ppm) and U. bismolliuscula (530 ppm), whereas the extract of $P$. tinctorum $(710 \mathrm{ppm})$ and $P$. aurata $(660 \mathrm{ppm})$ showed aluminium as the third highest element. Therefore, the mineral content of $R$. taitensis and $U$. bismolliuscula was found to be in the order of calcium $>$ potassium $>$ magnesium and aluminium but the extract of $P$. tinctorum was in the order of calcium $>$ potassium $>$ magnesium and P. aurata was in the order of aluminium $>$ calcium $>$ potassium $>$ phosphorous. The extract of $R$. taitensis was found to possess more amount of calcium content (3800 ppm). The extract of P. tinctorum was found to have the highest potassium content. The aluminium content was high in the extract of $P$. tinctorum with the value of $710 \mathrm{ppm}$. In the case of $P$. aurata, the iron and magnesium and zinc contents showed higher concentrations than other lichen sample extracts. The mineral content of cobalt and cadmium were the least quantity of all lichen extracts.

Vital minerals such as calcium (3800 ppm) and magnesium (710 ppm) were abundant in $R$. taitensis, and Sodium (200 ppm) and phosphorous were maximum in $P$. tinctorum compared to other lichens. Trace elements like $\mathrm{Sr}, \mathrm{Fe}, \mathrm{B}, \mathrm{Zn}, \mathrm{Al}, \mathrm{Si}, \mathrm{Mn}$, and $\mathrm{Cu}$ also detected in all the analyzed lichens. 
Table 2. Quantitative mineral element content of phytochemicals in lichen extracts

\begin{tabular}{lllll}
\hline & $\begin{array}{l}\text { P. tinctorum } \\
(\mathrm{ppm})\end{array}$ & $\begin{array}{l}\text { P. aurata } \\
(\mathrm{ppm})\end{array}$ & $\begin{array}{l}\text { R. taitensis } \\
(\mathrm{ppm})\end{array}$ & $\begin{array}{l}\text { U. bismolluscula } \\
(\mathrm{ppm})\end{array}$ \\
\hline $\mathrm{Ca}$ & 1500 & 2500 & 3800 & 2000 \\
$\mathrm{Mg}$ & 510 & 420 & 710 & 530 \\
$\mathrm{Na}$ & 200 & 180 & 140 & 80 \\
$\mathrm{Sr}$ & 19 & 15 & 25 & 10 \\
$\mathrm{~K}$ & 2000 & 1500 & 1600 & 1000 \\
$\mathrm{Fe}$ & 239 & 390 & 290 & 150 \\
$\mathrm{~B}$ & 45 & 30 & 23 & 37 \\
$\mathrm{Zn}$ & 15 & 25 & 13 & 10 \\
$\mathrm{Al}$ & 710 & 660 & 340 & 460 \\
$\mathrm{Si}$ & 230 & 260 & 320 & 290 \\
$\mathrm{P}$ & 460 & 430 & 180 & 110 \\
$\mathrm{Mn}$ & 90 & 82 & 74 & 56 \\
$\mathrm{Cu}$ & 3.5 & 4.6 & 1.5 & 1 \\
$\mathrm{Co}$ & 0.1 & 0.4 & 0.5 & 0.2 \\
$\mathrm{Cr}$ & 0.2 & 0.7 & 1.2 & 1 \\
$\mathrm{Ni}$ & 1 & 1.2 & 1.4 & 1.2 \\
$\mathrm{~Pb}$ & 40 & 28 & 30 & 17 \\
$\mathrm{Cd}$ & 0.1 & 0.3 & 0.5 & 0.2 \\
\hline
\end{tabular}

\subsubsection{Amino acids profiling of lichen samples}

The amino acid composition of the lichen sample is shown in Figure 1. It was found that the proteins of the lichen contained adequate levels of amino acids. A total number of eighteen amino acids were identified from the studied samples. The estimated value of eight essential amino acids were found to be detected in all the four lichens. The amino acid glycine $(0.27 \mathrm{mg} / \mathrm{g})$ was a dominant in $P$. aurata followed by alanine $(0.25 \mathrm{mg} / \mathrm{g})$, arginine $(0.19 \mathrm{mg} / \mathrm{g})$, tryptophan $(0.18 \mathrm{mg} / \mathrm{g})$, aspartic acid $(0.17 \mathrm{mg} / \mathrm{g})$. Glutamine $(0.87 \mathrm{mg} / \mathrm{g})$, histidine $(0.52 \mathrm{mg} / \mathrm{g})$, isoleucine $0.37 \mathrm{mg} / \mathrm{g}$, serine $(0.15 \mathrm{mg} / \mathrm{g})$ and threonine $(0.43 \mathrm{mg} / \mathrm{g})$ were higher in $P$. tinctorum. $R$. taitensis had its dominant amino acids of cystine $(0.18 \mathrm{mg} / \mathrm{g})$, isoleucine $(0.37 \mathrm{mg} / \mathrm{g})$, leucine $(0.39 \mathrm{mg} / \mathrm{g})$, lysine $(0.71 \mathrm{mg} / \mathrm{g})$, methionine $(0.37 \mathrm{mg} / \mathrm{g})$ and phenylalanine $(0.53 \mathrm{mg} / \mathrm{g})$. The amino acids of asparagine $(0.27 \mathrm{mg} / \mathrm{g})$, glutamic acid $(90.63 \mathrm{mg} / \mathrm{g})$ were more abundant in U. bismolliuscula.

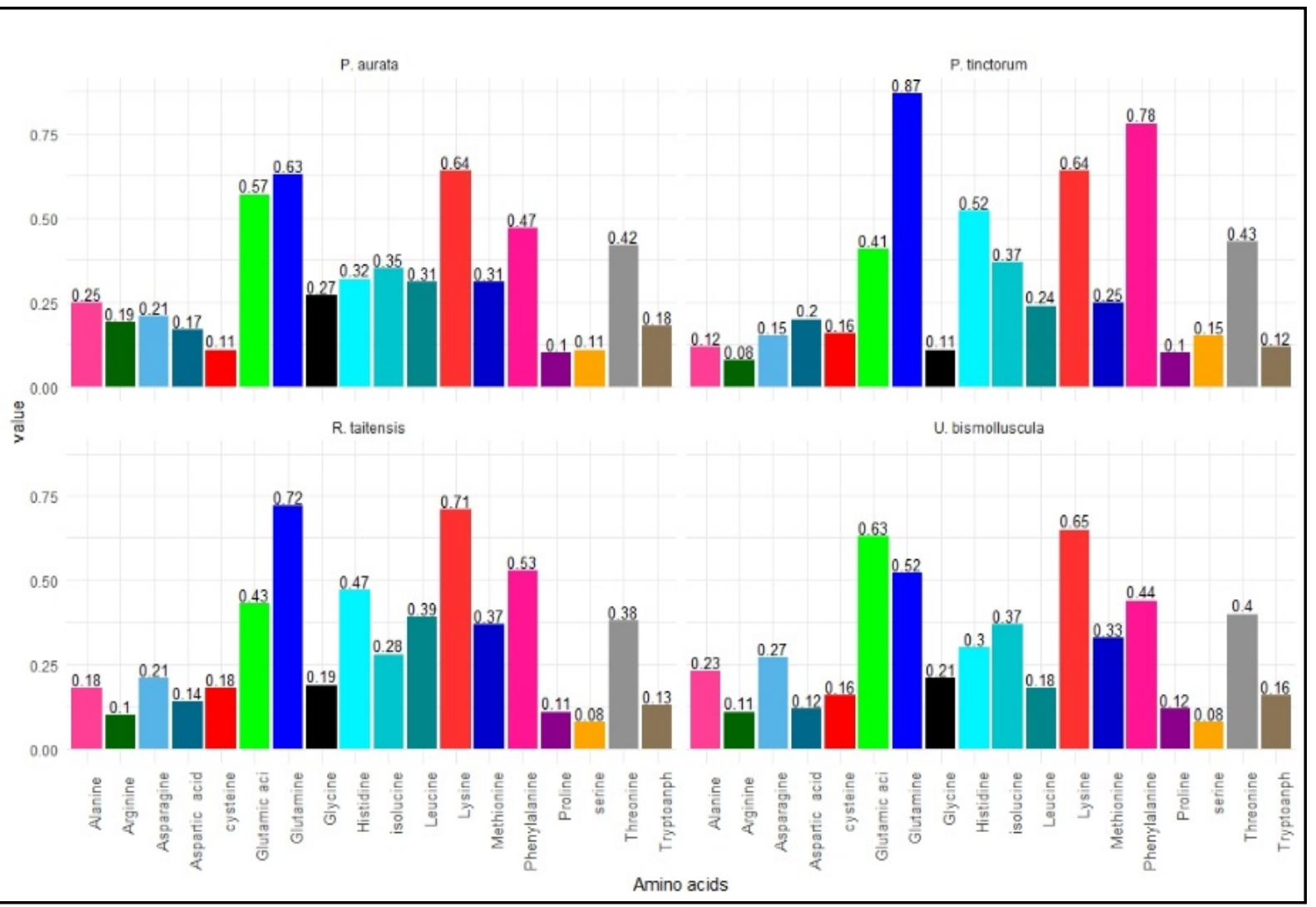

Figure 1. Amino acid profile of lichen extracts

\subsubsection{Total phenolic content of lichen samples}

Phenol plays an important role in scavenging free radicals present in the body. The TPC in $P$. tinctorum, $P$. aurata, $R$. taiensis and $U$. bismolliuscula extracts were compared with the linear gallic acid standard curve. The phenolic amounts found in test samples of different lichen extracts were statistically evaluated and findings are shown in Table 3. The methanol extract of all the four lichen species showed a high amount of phenolic compound. In $R$. taitensis, it was $86.14 \pm 1.42 \mathrm{mg} \mathrm{GAE} / \mathrm{g}$ extract while $U$. bismolluscula had $55.60 \pm 1.11 \mathrm{mg}$
GAE/g followed by $P$. aurata with the value of $40.4 \pm 1.07$ GAE/g extract and P. tinctorum had $39.5 \pm 1.29 \mathrm{mg}$ GAE/g extract. The aqueous extracts of $U$. bismolliuscula showed the lowest phenolic content with the concentrations of $4.9 \pm 1.31 \mathrm{GAE} / \mathrm{g}$ extract. The study was carried out following the method of Ng et al. (2020b) and Lapido et al. (2011). The considerable variation in total phenolic content was observed in our present study with the highest concentration of $86.14 \pm 1.42 \mathrm{mg}$ GAE / g extract in the methanol extract of $R$. taintesis. 
Table 3. Estimation of total phenolics, flavonoids and ABTS radical scavenging activities, phosphomolybdenum, of lichen samples

\begin{tabular}{|c|c|c|c|c|c|}
\hline Samples & Extracts & $\begin{array}{l}\text { Total phenolics mg } \\
\text { GAE / g extract }\end{array}$ & $\begin{array}{l}\text { Total flavonoids mg RE / } \\
\text { g extract }\end{array}$ & $\begin{array}{l}\text { ABTS } \\
\text { (mM TE/g extract) }\end{array}$ & $\begin{array}{l}\text { Phospomolbdenum } \\
\text { (mg AAE/g extract) }\end{array}$ \\
\hline \multirow{4}{*}{ P. tinctorum } & Petroleum ether & $7.38 \pm 0.10^{j}$ & $8.63 \pm 0.06^{1}$ & $29.11 \pm 1.06^{\mathrm{n}}$ & $27.78 \pm 1.18^{\mathrm{i}}$ \\
\hline & Acetone & $39.5 \pm 1.29^{c}$ & $17.6 \pm 1.08^{\mathrm{e}}$ & $50.2 \pm 4.9^{\mathrm{f}}$ & $37.00 \pm 0.53^{h}$ \\
\hline & Methanol & $26.4 \pm 1.15^{\mathrm{d}}$ & $25.8 \pm 1.10^{\mathrm{d}}$ & $73.7 \pm 5.2^{b}$ & $42.56 \pm 1.35^{\mathrm{g}}$ \\
\hline & Water & $9.15 \pm 1.21^{\mathrm{I}}$ & $5.9 \pm 1.07^{\mathrm{n}}$ & $35.62 \pm 0.03_{i}$ & $31.62 \pm 0.29^{j}$ \\
\hline \multirow{4}{*}{ P. aurata } & Petroleum ether & $11.26 \pm 0.03^{\mathrm{h}}$ & $7.73 \pm 0.05^{\mathrm{m}}$ & $17.6 \pm 6.10^{\circ}$ & $27.35 \pm 1.74^{\mathrm{i}}$ \\
\hline & Acetone & $16.3 \pm 2.04^{\mathrm{f}}$ & $10.6 \pm 1.07^{\mathrm{c}}$ & $42.7 \pm 5.11^{\mathrm{g}}$ & $50.68 \pm 1.15^{f}$ \\
\hline & Methanol & $40.4 \pm 1.07^{\mathrm{b}}$ & $26.9 \pm 1.14^{\mathrm{j}}$ & $62.3 \pm 15.1^{c}$ & $68.54 \pm 1.64^{\mathrm{d}}$ \\
\hline & Water & $13.8 \pm 0.01^{\mathrm{g}}$ & $3.6 \pm 1.03^{\circ}$ & $37.15 \pm 0.04^{h}$ & $59.74 \pm 2.03^{e}$ \\
\hline \multirow{4}{*}{ R. taitensis } & Petroleum ether & $12.01 \pm 1.02^{\mathrm{h}}$ & $14.4 \pm 1.088^{\mathrm{g}}$ & $29.5 \pm 5.06^{\mathrm{m}}$ & $55.81 \pm 0.08^{f}$ \\
\hline & Acetone & $22.87 \pm 0.12^{\mathrm{e}}$ & $11.7 \pm 1.10^{\mathrm{f}}$ & $30.4 \pm 1.9^{1}$ & $87.26 \pm 0.39^{b}$ \\
\hline & Methanol & $86.14 \pm 1.42^{\text {a }}$ & $17.04 \pm 0.04^{h}$ & $53.12 \pm 6.5^{\mathrm{e}}$ & $150.68 \pm 1.15^{\mathrm{a}}$ \\
\hline & Water & $6.3 \pm 1.06^{\mathrm{k}}$ & $9.5 \pm 1.08^{\mathrm{k}}$ & $14.2 \pm 7.4^{\mathrm{p}}$ & $63.24 \pm 0.391^{\mathrm{e}}$ \\
\hline \multirow{4}{*}{ U. bismolliuscula } & Petroleum ether & $12.58 \pm 0.082^{h}$ & $11.36 \pm 0.05^{\mathrm{i}}$ & $35.1 \pm 6.1^{\mathrm{j}}$ & $72.47 \pm 2.15^{c}$ \\
\hline & Acetone & $14.7 \pm 1.04^{\mathrm{e}}$ & $30.05 \pm 1.17^{\mathrm{b}}$ & $60.3 \pm 14.2^{\mathrm{d}}$ & $51.196 \pm 0.78^{\mathrm{f}}$ \\
\hline & Methanol & $55.60 \pm 1.11^{\mathrm{a}}$ & $31.2 \pm 1.10^{\mathrm{a}}$ & $85.6 \pm 0.5^{\mathrm{a}}$ & $87.78 \pm 0.48^{b}$ \\
\hline & Water & $4.9 \pm 1.31^{\mathrm{k}}$ & $10.4 \pm 1.01^{\mathrm{j}}$ & $32.3 \pm 2.19^{k}$ & $71.93 \pm 0.25^{c}$ \\
\hline
\end{tabular}

Values are mean of triplicate determination $(n=3) \pm$ standard deviation, $\%$ - \% of Inhibition.

GAE-Gallic Acid Equivalents, RE- Rutin, TE- Trolox Equivalents. AAE- Ascorbic Acid Equivalents.

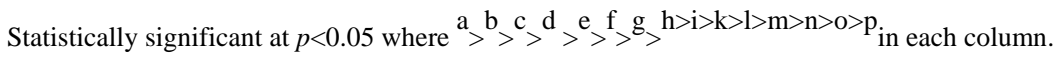

The results of the present study are strongly supportive in agreement to the findings of Rice-evans et al. (1995) and Singleton et al. (1999) that the TPC content of lichen extracts are responsible for antioxidant and biological activities of lichen extracts. Ganesan et al. (2015). Observed that the TPC value was significantly higher in the extract of benzene (154.2 mg GAE/g) than in other $P$. tinctorum extracts and reported that the availability of phenolic content sources could trigger the activity of lichen metabolites which probably play a subtle role in antimicrobial and antioxidant activities. The results are not in agreement with the report given by Ganesan et al., (2015). The relative TPC values of lichen or tested plants may be varied due to age of the plant, methods of extraction procedure, choice of solvents, number of replicates used for investigation etc. Singleton et al. (1999) observed the number of phenolic groups in their native structure and reported that this may have the major reason for difference found between biological activities of lichen extracts. Rice-Evans et al. (1995) reasoned phenolic compound has the high potency of antioxidants because it acts as the single oxygen quenchers and oxygen donors. As reported, the acetone extracts of $P$. austrosinense and $P$. tinctorum exhibited high TPC corresponding to its high free radical scavenging activities (Kalidoss et al., 2019).

\subsubsection{Total flavonoid content of lichen samples}

The TFC was determined in P. tinctorum, P. aurata, $R$. taiensis and $U$. bismolliuscula and the results are presented in the Table 3. The highest TFC was observed in methanol extracts of $U$. bismolluscula (31.2 $\pm 1.10 \mathrm{mg} \mathrm{RE} / \mathrm{g}$ extract) followed by $P$. aurata ( $26.9 \pm 1.14 \mathrm{mg} \mathrm{RE} / \mathrm{g}$ extract) and $P$. tinctorum ( $25.8 \pm 1.10 \mathrm{mg} \mathrm{RE} / \mathrm{g}$ extract) and $R$. taitensis (17.04 $\pm 0.04 \mathrm{mg} \mathrm{RE} / \mathrm{g}$ extract). The aqueous extracts of $P$. aurata was found to be lower $(3.6 \pm 1.03 \mathrm{mg} \mathrm{RE} / \mathrm{g}$ extract). The results reported by Ng, Koick and Yong (2020a) are strongly supportive in agreement to the present investigation that the flavonoid and phenolic constituents of plant extracts are considered to be beneficial for health particularly for the antioxidant action. Thus, the use of lichen extracts for health benefits particularly for nutraceutical applications can be justified on the basis that these lichens were once thought to be medicinal is really due to their TPC, TFC and other chemical constituents.

\subsection{In vitro antioxidant assays}

\subsubsection{DPPH radical scavenging activity}

The DPPH radical scavenging activities of different lichen extracts of $P$. tinctorum, $P$. aurata $R$. taiensis and $U$. bismolliuscula are shown in the Figure 2 . The $\mathrm{IC}_{50}$ values (concentration of sample required to scavenging $50 \%$ of free radicals) were calculated from the regression equation prepared from the concentration of the extracts versus percentage inhibition of free radical formation. A lower $\mathrm{IC}_{50}$ value indicates the greater $\mathrm{DPPH}$ radical scavenging activity. Among the all the lichens analysed the acetone extract of $P$. aurata shows lower $\mathrm{IC}_{50}$ value of $93.339 \mu \mathrm{g} / \mathrm{mL}$ than the acetone extract of $U$. bismolluscula $(106.786 \mu \mathrm{g} / \mathrm{mL})$, petroleum ether extract of $R$. taitensis $146.9266 \mu \mathrm{g} / \mathrm{mL}$ and acetone extract of P.tinctorum $(162.488 \mu \mathrm{g} / \mathrm{mL})$. The petroleum ether extract of $P$. tinctorum shows minimal antioxidant activity with the highest $\mathrm{IC}_{50}$ value of $372.825 \mu \mathrm{g} / \mathrm{mL}$. The $\mathrm{IC}_{50}$ value for ascorbic acid $(20.32 \mu \mathrm{g} / \mathrm{mL})$ standard employed in DPPH assay of the present study is closer to the value given by $\mathrm{Ng}$ et al. (2020c). The present study showed significant half the inhibition concentration of ascorbic acid standard with the $\mathrm{IC}_{50}$ value of $20.32 \mu \mathrm{g} / \mathrm{mL}$ as compared to 23.45 $\mathrm{mmol} / \mathrm{L}$ showed by $\mathrm{Ng}$ et al. (2019). 


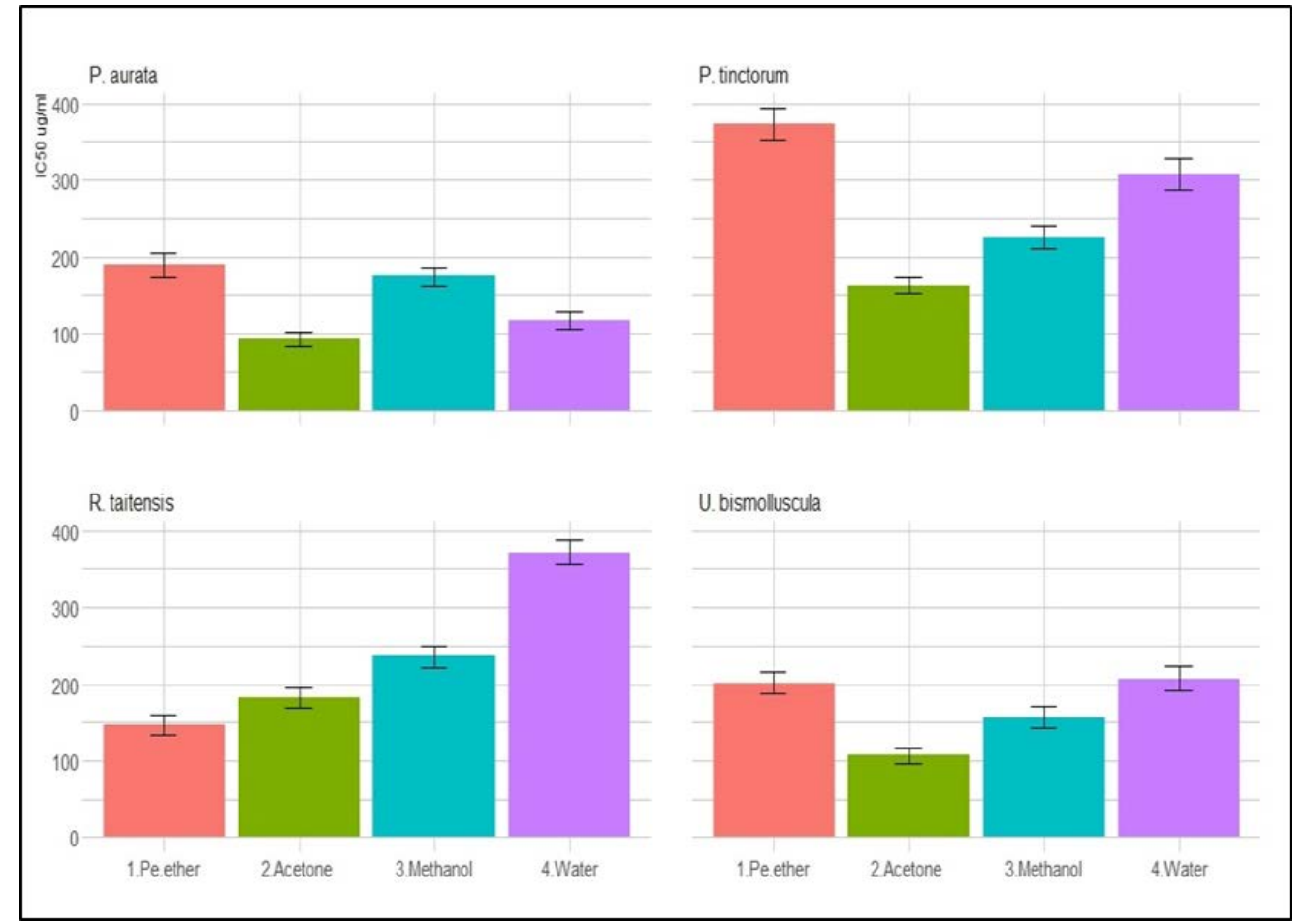

Figure 2. DPPH radical scavenging activity of lichen extracts

\subsubsection{Superoxide anion radical scavenging activity}

Superoxide anion radical scavenging activities of $P$. tinctorum, $P$. aurata $R$. taiensis and $U$. bismolliuscula were analysed, and the results are shown in Figure 3. The extracts were found to be containing high scavenging potential of superoxide radicals generated in riboflavinNBT- light system. The water extract of $P$. tinctorum, was showing higher (83 \%) scavenging potential than the other extracts. The minimum activity with the $\mathrm{IC}_{50}$ value was found in acetone extract of $P$. aurata $(0.78 \%)$. The result proves that the percentage of inhibition is based on the concentration of the bioactive phenolic compounds present in solvent extract.

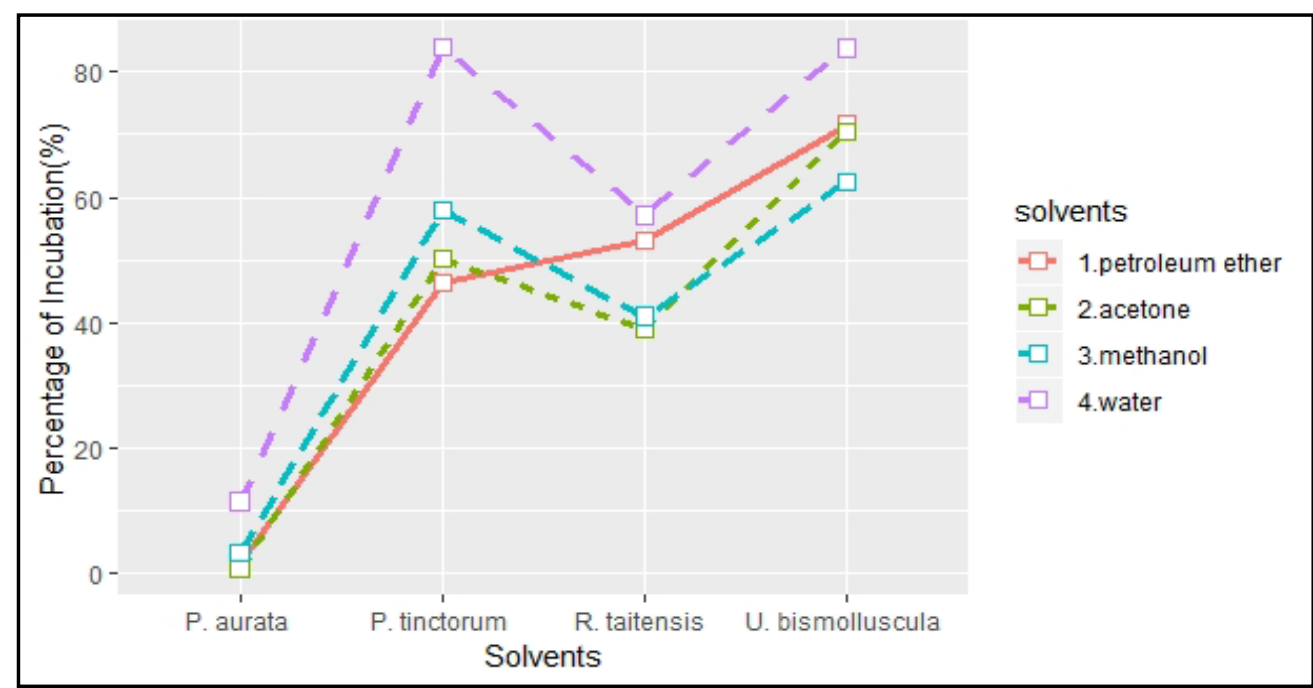

Figure 3. Superoxide radical scavenging activity of lichen extracts

\subsection{3. $\mathrm{ABTS}^{+}$radical scavenging activity}

The extracts of P. tinctorum, $P$. aurata $R$. taiensis and $U$. bismolliuscula showed their antioxidant activities with regard to ABTS scavenging abilities (Table 3). The methanol extracts of $U$. bismolliuscula showed highest ABTS scavenging activity with the value of $85.6 \pm 0.5$ $\mathrm{mM}$ TE/g extract. The methanol extract of $P$. tinctorum and $P$. aurata showed moderate activity with the values of $73.7 \pm 5.2$ and $62.3 \pm$
$15.3 \mathrm{mM} \mathrm{TE} / \mathrm{g}$ extract respectively. However, the methanol extracts of $R$. taiensis showed minimal scavenging values $(53.12 \pm 6.5 \mathrm{mM} \mathrm{TE} / \mathrm{g}$ extract). The values of the various extracts of lichens for the ABTS scavenging activity falls in the order of $U$. bismolliuscula $>P$. tinctorum $>P$. aurata $>R$. taiensis respectively. The standard rutin showed strong ABTS scavenging activity (111.3 $\pm 0.52 \mathrm{mM} \mathrm{TE} / \mathrm{g}$ extract). Compared to that of standard rutin, moderate ABTS scavenging activity was observed in the methanol extract of $U$. bismolliuscula (highest value of $85.6 \pm 0.5 \mathrm{mM} \mathrm{TE} / \mathrm{g}$ extract) in the 
present study. Similar study conducted by $\mathrm{Ng}$ et al. (2020a) showed $0.01 \mathrm{mg} / \mathrm{mL}$ for trolox standard as compared to $111.3 \pm 0.52 \mathrm{mM} \mathrm{TE} / \mathrm{g}$ extract for rutin in the present study. Variations in the values are due to variations in the test standard.

\subsubsection{Phosphomolybdenum reduction assay}

The phosphomolybdenum assay was mostly used to measure the total antioxidant activity of substances and the results are presented in the Table 3 . Among the different extracts $P$. tinctorum, $P$. aurata, $R$. taiensis and $U$. bismolliuscula, methanol extracts of $R$. taiensis showed highest value of reducing ability compared with other extracts (150.68 $\pm 1.15 \mathrm{mg} \mathrm{AAE} / \mathrm{g}$ extract). The methanol extracts of $P$. tinctorum, $P$. aurata and $U$. bismolliuscula were found to have moderate level of antioxidant activity with the concentrations of $42.56 \pm 1.35,68.54 \pm 1.64$ and $87.78 \pm 0.48 \mathrm{mg} \mathrm{AAE} / \mathrm{g}$ extract respectively. The rutin standard showed maximum activity (158.39 $\pm 1.79 \mathrm{mg}$ AAE/ g extract) compared with lichen extracts in phosphomolybdenum reduction assay. The study carried out in methanol extracts of four lichen thalli showed maximum phopshomolybdenum activity when compared to the other solvent extracts. The phosphomolybdenum reduction value in methanol extract of $R$. taitensis is closer to the rutin standard.

\section{Discussion}

The nutritional constituents of two foliose and two fruticose forms of lichen species were documented as described by $\mathrm{Hu}$ et al. (2020); Rahman et al. (2018); Kekuda, et al. (2011); Joubert et al. (1982). The previous literature asserted that the nutritional contents of lichens such as tannins, flavonoids and phenolics are being used as medicine and can be useful to fortify them in human foods. Lichens and plants differ considerably in phytochemical constituents. Since many wild animals and mammals eat lichen as diets, it is vital to measure the nutritional content of lichens. The nutrient content of foliose lichen was comparable with fruticose lichen in all macro element parameters except ash content. The moisture content of the four different lichens was found to be in the order of $P$. tinctorum $>R$. taiensis $>U$. bismolliuscula $>P$. aurata. This may be the reason to suggest the the $P$. tinctorum weighs heavier than other lichens.

Compared with foliose forms, fruticose lichens were deficient in starch and ash content. Fruticose were also lower in energy than foliose lichen. Many lichen species are also shown to be eaten by many mammals such as redbacked voles, deer and squirrels and thereby may play an important role in economic botany as nutritional benefits to plants and animals.

Previous literatures have shown that organic solvents are generally used for extraction of lichen metabolites because lichen substances are either insoluble or partial soluble in water. Most organic solvent-soluble antioxidants are either bound to cortex or medulla in lichen thalli. Solvent extracts from test samples of four different lichen thalli responded effectively to various biological assays in the present investigation. The extract of a particular lichen substance influences the efficiency of biological assays and is based on the polarity of solvent.
According to Sarker et al. (2006), the use of organic solvent, methanol for extraction of metabolites to winged been seeds has been successful because these affected easy extraction process in many ways and that the methanol penetrated the thick seed coat structure and promoted fast recovery of plant nutrients. The mechanism behind the effect of solvent property may also depend on the electrontransfer kinetic mechanism and physiochemical properties (lipophilic and hydrophilic properties) of the phytochemical compounds. Previous records have shown that the ideal solvent examined for extracting the antioxidant compounds of $P$. tetragonolobus was methanol in antioxidant assays ( $\mathrm{Ng}$ et al., 2020b). This is in agreement with our findings that the methanol extract of all the four lichens had the highest radical scavenging activity and the values are comparable to the standard.

The use of petroleum ether and water had found negative effects in the present study on ABTS, DPPH, superoxide scavenging and phopshomolybdenum reduction assays by-showing the week activity (the highest $\mathrm{IC}_{50}$ or low $\mathrm{mM} \mathrm{TE} / \mathrm{mg}$ values) with minimal antioxidants to scavenge radicals inhibiting cellular damage. The primary reason for lowest antioxidant activity may be attributed to the relative total antioxidant contents possessed in solvent extracts. Similarly, the considerable variation in types of substances or antioxidants has also been observed in the present investigation, thus they reacted differently to the range of solvents on the basis of their polarity. The radical scavenging activity suggested a contrast between the electron transfer kinetic mechanism of substances in solvent extracts. The DPPH radical scavenging power is attributed to the lipophilic antioxidants while, the ABTS antioxidant assay detects lipophilic and hydrophilic substances (Ng \& See 2019) in the extracts indicating the differences in the antioxidant activity between these two scavenging assays.

The antioxidant activity may also be affected by enzymatic antioxidants. Previous literature indicated that the metabolite accumulation in plant part infers the induction of defence mechanism. Therefore, under abiotic stress, enzymatic antioxidants like, Superoxide dismutase and Quinone oxidoreductase are induced for scavenging reactive oxygen species (ROS). Superoxide dismutase play a significant role in the catalytic conversion of highly reactive superoxide anions to oxygen molecule while the quinone oxidoreductase enzymatic antioxidant involves in the conversion of highly reactive quinone to less reactive hydoxy quinones. This process of conversion of ROS is termed redox homeostasis defence mechanism (Ng et al., 2014). The same reason may also be applicable to the present investigation that the level of enzymatic antioxidants in different solvent extracts might influence radical scavenging activities in antioxidant assays.

\subsection{Proximate composition of samples}

All the macro and micro nutrients estimated were found to be higher in fruticose form than in foliose form of lichen (Table 1). The results showed that the former had the profuse development and growth when compared to the latter. The mean average total carbohydrate and protein contents were higher in fruticose (54.32 and $19.525 \mathrm{mg}$ glucose equivalent respectively) than in foliose (48.115 and $18.715 \%$ respectively) but there was no significant difference drawn between foliose and fruticose forms of 
lichen in the amount of macronutrient. Kirkpatrick (1996) found that Bryoria spp., contained considerable quantities of soluble carbohydrates and pointed out that it had low fiber and phenolic contents. Robbins (Robbins 1987) found that the crude protein content of Alectoria sarmentosa lichen was just $2 \%$ and an outcome was nitrogen losses in feces of mule deer.

Starch content was found to be $0.17 \pm 0.03 \mathrm{mg}$ glucose equivalents/g of samples in foliose followed by $0.13 \pm$ $0.05 \mathrm{mg}$ in fruticose lichens. Similar to that of macroelements, the mean average ash content was more pronounced in foliose lichen (7.93\%) followed by fruticose (3.42\%) lichens. Moreover, such differences are determined experimentally, and the results were affected by environmental conditions such as air, $\mathrm{pH}$ of the substrata, temperature ...etc. There were no correlations between moisture and macro nutrient content in lichen growth forms (Table 1).

Thallus of $P$. tinctorum had a greater amount of ash content at $13.93 \%$ when compared to $R$. taiensis at $4.41 \%$. The ash content of $U$. bismolliuscula thallus was found to be $2.43 \%$ higher than $1.93 \%$ of $P$. aurata. The nutritional studies (Table 1) with thallus of foliose and fruticose lichen showed differences in starch, protein and total carbohydrate. This shows the significance of incorporating ash content in the analysis as majority of the nutritional content is included in the ash.

It follows from the results that foliose and fruticose lichen significantly differ in their nutritional values. Such differences are determined experimentally and may also be influenced by the nature of thallus.

\subsection{Mineral composition of lichen samples}

Carbohydrates, proteins, fats and vitamin constituents are more common in all plants determining the nutritional quality of any forage. This macro nutrient together with micro elements form a fodder for reindeer, caribou, squirrels. These micronutrients have been described to have many physiological functions such as anti-oxidant defence activity, electrolytic activity, components of enzymes, gas transport, regulate cellular energy transduction and regulate physcio-chemical processes. Therefore, these microelements play a vital role on all living matter. The result of the present study is in accordance with Vinayaka et al. (2013) reported the content of calcium was highest among all other elements in $U$. pictoides. Similar result was obtained by Kekuda et al. (2011) for the lichen extracts of Everniastrum cirrhatum where the content of calcium was highest among all micronutrients. The reason for the difference in microelements is probably due to variation in abiotic and biotic factors viz., habitats, age of lichen, solvent used for extraction procedure and origin of plant materials.

\subsection{Amino acids profiling of lichen samples}

It was found that the lichen extracts contained sufficient amount of amino acids as compared to reports from WHO/ FAO 2007. The comprehensive outcome of this research culminates in the assumption that glutamine has a higher volume relative to all other amino acids in $P$. tinctorum in the present study. Supportive finding was recorded from Jäger and Weigel (1978) who reported that a conceivable intention for this similarity is that glutamine seems to play important role in nitrogen fixation and
Pseudevernia furfuracea (L.) Zopf was possessing high amounts of glutamic acid, aspartic acid, alanine, arginine, and taurine etc. Shelukheeva and Nikolaeva (2015) reported that amino acid content of Cetraria islandica and C. laevigata was found to possess 16 different amino acids, of which seven were essential. The present study detected 18 different amino acids from four different lichen samples.

\subsection{Estimation of total phenolic content (TPC)}

Singleton et al. (1999) observed the number of phenolic groups in their native structure and reported that this may have the major reason for variation in biological activities of lichen extracts. Rice-Evans et al. (1995) reasoned phenolic compound has the high potency of antioxidants because it acts as the single oxygen quenchers and oxygen donors. As reported, the acetone extracts of $P$. tinctorum exhibited high phenolic content corresponding to its strong free radical scavenging activity.

\subsection{1.5. Estimation of total flavonoid content (TFC)}

In the present study, highest TFC was observed in the methanol extract of $U$. bismolliuscula $31.2 \pm 1.10 \mathrm{mg} \mathrm{RE}$ $\mathrm{g}$ while the least was in the aqueous extract of $P$. aurata $3.6 \pm 1.03 \mathrm{mg} \mathrm{RE} / \mathrm{g}$. But, Ganesan et al. (2015) observed that the TFC of lichen extracts ranged from 20.16 to 50.72 $\mathrm{mg} \mathrm{RE} / \mathrm{g}$, and the higher content was found in aqueous extract $50.72 \pm 0.13$ and lower in ethanolic extract $20.16 \pm$ $0.11 \mathrm{mg} \mathrm{RE} / \mathrm{g}$. The results of the present study are in line with the Raj et al. (2014) reported that the total flavonoid and phenolic contents of Parmotrema tinctorum extracts were found to be $5.82 \pm 0.96 \mathrm{mg}$ quercetin equivalents/g and $9.67 \pm 0.73 \mathrm{mg}$ gallic acid equivalents/g of extract respectively.

\section{6. $D P P H$ radical scavenging activity}

DPPH scavenging assay was conducted to identify substantial antioxidant activity. DPPH is a free radical used to measure the scavenging potential of any phytochemical compounds. Among all four lichen extracts, the $\mathrm{IC}_{50}$ value of acetone extract of $P$. aurata (93.339 $\mu \mathrm{g} / \mathrm{ml}$ ) is comparable to that of ascorbic acid (20.32 $\mu \mathrm{g} / \mathrm{ml}$ ). The DPPH scavenging results are supportive in agreement to Ristic et al. (2016) where lecanoric acid showed weak activity with the highest IC $_{50}$ value of $424.51 \mu \mathrm{g} / \mathrm{mL}$. Thus, this suggested that the polarity of solvent extract that determines the DPPH radical scavenging activity of phytochemical compounds.

\subsection{Superoxide anion radical scavenging activity}

The biological enzyme XO (xanthine oxidase) has significance in catalysing the bioconversion of hypoxanthine to xanthine and to uric acid while the SOD (superoxide dismutase) in superoxide into hydrogen peroxide and oxygen in biological tissues. The superoxide radical scavenging activity of the present analysis is in accordance with the Behera et al. (2016) who reported that the methanol extract of $U$. ghattensis exhibited strong activity with the value of $56 \%$. The secondary metabolite of $U$. ghattensis contains usnic acid. The known standards BHA, BHT and quercetin showed scavenging activity with the value of 59, 68 and $47 \%$ respectively. Kosanić et al. (2014) found that highest super oxide anion scavenging activity (67.37\%) was observed in the acetone extracts of the lichen Lasallia pustulata. Aqueous extract of lichen 
Parmelia sulcata showed the least scavenging activity (12.74\%). The $P$. tinctorum aqueous extract of the present study showed the strong scavenging activity with the $87 \%$ while the weak activity was observed in acetone extracts of $P$. aurata with the lowest value of $0.78 \%$.

\subsection{ABTS $^{+}$radical scavenging activity}

The comparison of the secondary metabolites of the tested lichen extracts and their free radical scavenging ability revealed a strong correlation with the previous study conducted by Raj et al. (2014). The solvent of choice greatly influenced the ABTS scavenging activity in extracts of all the four different lichen samples. This ethyl acetate extract of $P$. tinctorum exhibited significant antioxidant potential against ABTS with half the inhibitory concentrations of $151.34 \pm 1.79 \mathrm{mg} / \mathrm{mL}$ and the results are supportive in agreement to the previous literature depicted that the antidiabetic nutraceutical properties have been identified from $P$. tinctorum samples. In the present study, petroleum ether and aqueous extract of $P$. tinctorum showed less activity when compared with acetone and methanol extracts. The highest activity was shown in methanol extract $(85.6 \pm 0.5 \mathrm{mM} \mathrm{TE} / \mathrm{g}$ extract) of $U$. bismolliuscula followed by the $P$. tinctorum extract (73.7 \pm $5.2 \mathrm{mM}$ TE/g extract). The results of ethyl acetate extract of $P$. tinctorum are supportive in agreement to the report given by Raj et al. (2014). Ganesan et al. (2017) found that methanol extract of Ramalina inflata $(80 \mu \mathrm{g} / \mathrm{ml})$ was significantly lower than benzene extract $(100 \mu \mathrm{g} / \mathrm{ml})$ of those recorded in the fructicose lichen. The results of the present study are consistent with the report of Ganesan et al. (2017), in that the antioxidant activity in the petroleum ether extract was lower than that of the other extracts. The results of ethanol extract of $U$. longissima are in accordance with the findings of Aydin et al. (2018) who reported that ABTS radical scavenging assay for $U$. longissima ethanol extract and ethyl acetate were found as $73.31 \pm 0.007 \%$ at $4000 \mu \mathrm{g} / \mathrm{mL}$ and $54.92 \pm 0.010 \%$ at $4000 \mu \mathrm{g} / \mathrm{ml}$ respectively. Compared with standard control, in the present study, ABTS radical scavenging activity of acetone extract of $U$. bismolliuscula was found to be high (60.3 $\pm 14.2 \mathrm{mM} \mathrm{TE} / \mathrm{g}$ extract) while the petroleum ether and aqueous extracts exhibited weak activity. The disparity in ABTS scavenging activity of lichen extracts may be due to variation in environment, lichen species, assessment methods and types of solvents used by researchers (Kazazic et al., 2016).

\subsection{Phosphomolybdenum reduction assay}

In the present study, strong antioxidant activity was amounted to $150.68 \pm 1.15 \mathrm{mg}$ AAE/ g for methanol extracts of Ramalina taitensis. Previous literature has reported the antioxidant properties of solvent extracts of many species of lichen, but the present study is the first attempt to document the phosphomolybdenum reduction assay of four different lichen extracts of commonly available lichen species such as $P$. tinctorum, $P$. aurata $R$. taitensis and $U$. bismolliuscula. The results showed that the methanol extract had a higher phenolic content (except $P$. tinctorum), which in turn exhibited strong antioxidant potency than the other extracts. The present result is in agreement with Dandapat and Paul (2019) who opined that methanol is an ideal solvent for extraction of lichen bioactive compounds for antioxidant activities. It is suggested that the increase in phenolic groups in chemical structure of lichen compounds can have corresponding increase in antioxidant activity. This is in conformity with the reports of Tomović et al. (2016).

The results of Manojlovic et al. (2012) are in accordance to the present study that the redox properties of phenolic content in methanol extract activated the neutralizing free radicals activity which play a subtle role in quenching triplet and singlet oxygen. They have shown that a significant difference in TPC was observed between chloroform (71.32 \pm 0.89$)$ and methanol extracts (79.2 \pm $0.59 \mathrm{mg} \mathrm{GA} / \mathrm{g}$ ) of Umblicaria cylindrica, and it was correlated with their antioxidant activity of $68.35 \pm 0.15$ $\mu \mathrm{g} \quad \mathrm{AA} / \mathrm{g}$ and $74.65 \pm 0.75 \mu \mathrm{g} \mathrm{AA} / \mathrm{g}$ respectively. Similarly, Tomović et al. (2016) reported the supportive results for total antioxidant capacity with the concentrations of $91.52 \pm 0.34 \mu \mathrm{g} \mathrm{AA} / \mathrm{g}$ and $71.5 \pm 0.29 \mu \mathrm{g}$ $\mathrm{AA} / \mathrm{g}$, for methanol and ethyl acetate extracts of Cetraria aculeata, respectively.

\subsection{Compound identification by Liquid \\ Chromatography Mass Spectrometry (LC/MS)}

The results obtained from the studies indicated that methanol extract showed higher activity than other solvents. The Liquid Chromatography Mass Spectrometry study was conducted to find out the active lichen compounds in test samples and the chromatogram are shown in the Figure $4 \& 5$. Major peaks with relative Mass spectral data were observed from chromatogram. The lichen compounds were detected based on their (Chemindex) library data base. The major lichen substances like atranorin, sekikaic acid, usnic acid, and other compounds identified are presented in Table 4. The findings are in line with the previous literature (Musharraf et al., 2015). Biologically important phytochemicals are present in $P$. tinctorum, $P$. aurata, $R$. taitensis and $U$. bismolliuscula. It can be suggested that the antioxidant activity is determined by their biologically active compounds in the solvent extract. 
Table 4. Compound Identification of lichen extract by LCMS method

\begin{tabular}{|c|c|c|c|c|c|}
\hline S.No & Compound Name & $\begin{array}{l}\text { Exact mass } \\
(\mathrm{m} / \mathrm{z})\end{array}$ & $\begin{array}{l}\text { Observed mass } \\
(\mathrm{m} / \mathrm{z})\end{array}$ & Precursor m/z & Molecular formula \\
\hline \multicolumn{6}{|c|}{ Parmotrema tinctorum } \\
\hline 1. & Diethanolamine & 105.14 & 105.00 & 117.01 -ve & $\mathrm{C}_{4} \mathrm{H}_{11} \mathrm{NO}_{2}$ \\
\hline 2. & Succinic acid & 118.09 & 118.12 & 119.03 +ve & $\mathrm{C}_{4} \mathrm{H}_{6} \mathrm{O}_{4}$ \\
\hline 3. & D-Carvone & 150.22 & 151.08 & & $\mathrm{C} 10 \mathrm{H} 14 \mathrm{O}$ \\
\hline 4. & Orsellinic acid & 168.15 & 169.04 & $\begin{array}{l}167.03 \text {-ve } \\
167.10 \text {-ve }\end{array}$ & $\mathrm{C}_{8} \mathrm{H}_{8} \mathrm{O}_{4}$ \\
\hline 5. & Eugenitol & 206.19 & 205.16 & $\begin{array}{l}205.04 \text {-ve } \\
207.06 \text { +ve }\end{array}$ & $\mathrm{C}_{11} \mathrm{H}_{10} \mathrm{O}_{4}$ \\
\hline 6. & Volemitol & 212.2 & 213.03 & 211.08 -ve & $\mathrm{C}_{7} \mathrm{H}_{16} \mathrm{O}_{7}$ \\
\hline 7. & Lecanoric acid & 318.28 & 319.19 & $\begin{array}{l}317.06 \text {-ve } \\
317.06 \text {-ve }\end{array}$ & $\mathrm{C}_{16} \mathrm{H}_{14} \mathrm{O}_{7}$ \\
\hline 8. & Methyl protolichesterinate & 338.5 & 337.24 & & $\mathrm{C}_{20} \mathrm{H}_{34} \mathrm{O}_{4}$ \\
\hline 9. & Atranorin & 374.3 & 375.02 & 373.09 -ve & $\mathrm{C}_{19} \mathrm{H}_{18} \mathrm{O}_{8}$ \\
\hline 10. & Thamnolic acid & 420.3 & 421.21 & 419.06 -ve & $\mathrm{C}_{19} \mathrm{H}_{16} \mathrm{O}_{11}$ \\
\hline 11. & Perlatolic acid & 444.5 & 443.88 & 443.2 -ve & $\mathrm{C}_{25} \mathrm{H}_{32} \mathrm{O}_{7}$ \\
\hline 12. & Lobaric acid & 456.5 & 455.4 & 457.18 ive & $\mathrm{C}_{25} \mathrm{H}_{28} \mathrm{O}_{8}$ \\
\hline 13. & Leucotylin & 460.7 & 462.87 & & $\mathrm{C}_{30} \mathrm{H}_{52} \mathrm{O}_{3}$ \\
\hline \multicolumn{6}{|c|}{ Pseudocephallaria aurata } \\
\hline 14. & Succinic acid & 118.09 & 118.05 & $\begin{array}{l}117.01 \text {-ve } \\
119.03 \text { +ve }\end{array}$ & $\mathrm{C}_{4} \mathrm{H}_{6} \mathrm{O}_{4}$ \\
\hline 15. & 5,7Dihydroxy-6-methylphthalide & 180.04 & 178.06 & & $\mathrm{C}_{9} \mathrm{H}_{8} \mathrm{O}_{4}$ \\
\hline 16. & Chrysophanol & 254.24 & 254.14 & 255.06 +ve & $\mathrm{C}_{15} \mathrm{H}_{10} \mathrm{O}_{4}$ \\
\hline 17. & Conorlobaridone & 370.14 & 371.25 & & $\mathrm{C}_{21} \mathrm{H}_{22} \mathrm{O}_{6}$ \\
\hline \multicolumn{6}{|c|}{ Ramalina taitensis } \\
\hline 18. & Fumaric acid & 116.07 & 118.05 & 115.00 -ve & $\mathrm{C}_{4} \mathrm{H}_{4} \mathrm{O}_{4}$ \\
\hline 19. & D-Arabinose & 150.13 & 151.04 & 149.04 -ve & $\mathrm{C}_{5} \mathrm{H}_{10} \mathrm{O}_{5}$ \\
\hline 20. & Methyl orsellinate & 182.17 & 183.06 & 181.05 -ve & $\mathrm{C}_{9} \mathrm{H}_{10} \mathrm{O}_{4}$ \\
\hline 21. & Cholin sulphate & 183.05 & 184.12 & & $\mathrm{C}_{5} \mathrm{H}_{13} \mathrm{NO}_{4} \mathrm{~S}$ \\
\hline 22. & Methyl $\beta$-orcinolcarboxylate & 196.2 & 197.08 & 195.06 -ve & $\mathrm{C}_{10} \mathrm{H}_{12} \mathrm{O}_{4}$ \\
\hline 23. & Fukinanolide & 234.33 & 236.14 & & $\mathrm{C}_{15} \mathrm{H}_{22} \mathrm{O}_{2}$ \\
\hline 24. & Methyl porphyrilate & 328.13 & 330.12 & & $\mathrm{C}_{17} \mathrm{H}_{12} \mathrm{O}_{7}$ \\
\hline 25. & Usnic acid & 344.3 & 345.08 & 343.08-ve & $\mathrm{C}_{18} \mathrm{H}_{16} \mathrm{O}_{7}$ \\
\hline 26. & 3'-Dechlorolecideoidin & 364.03 & 367.23 & & $\mathrm{C}_{17} \mathrm{H}_{13} \mathrm{ClO}_{7}$ \\
\hline 27. & Sekikaic acid & 418.4 & 419.35 & 417.14 -ve & $\mathrm{C}_{22} \mathrm{H}_{26} \mathrm{O}_{8}$ \\
\hline \multicolumn{6}{|c|}{ Usnea bismolliuscula } \\
\hline 28. & Diethanolamine & 105.14 & 104.07 & & $\mathrm{C}_{4} \mathrm{H}_{11} \mathrm{NO}_{2}$ \\
\hline 29. & Indolyl-3-acetic acid & 175.18 & 175.04 & 176.06 +ve & $\mathrm{C}_{10} \mathrm{H}_{9} \mathrm{NO}_{2}$ \\
\hline 30. & Olivetolmonomethylether & 194.13 & 193.09 & & $\mathrm{C}_{12} \mathrm{H}_{18} \mathrm{O}_{2}$ \\
\hline 31. & Ethyl everninate & 210.23 & 211.11 & & $\mathrm{C}_{11} \mathrm{H}_{14} \mathrm{O}_{4}$ \\
\hline 32. & Olivetolcarboxylic acid & 224.25 & 225.17 & 223.09 -ve & $\mathrm{C}_{12} \mathrm{H}_{16} \mathrm{O}_{4}$ \\
\hline 33. & Fukinanolide & 234.33 & 236.14 & & $\mathrm{C}_{15} \mathrm{H}_{22} \mathrm{O}_{2}$ \\
\hline 34. & Linoleic acid & 280.4 & 279.27 & 279.23 -ve & $\mathrm{C}_{18} \mathrm{H}_{32} \mathrm{O}_{2}$ \\
\hline 35. & Usnic acid & 344.3 & 345.08 & 343.08 -ve & $\mathrm{C}_{18} \mathrm{H}_{16} \mathrm{O}_{7}$ \\
\hline 36. & 4-O-Methyl-5-dechlorovicanicin & 362.09 & 363.10 & & $\mathrm{C}_{19} \mathrm{H}_{19} \mathrm{ClO}_{5}$ \\
\hline
\end{tabular}


(A)

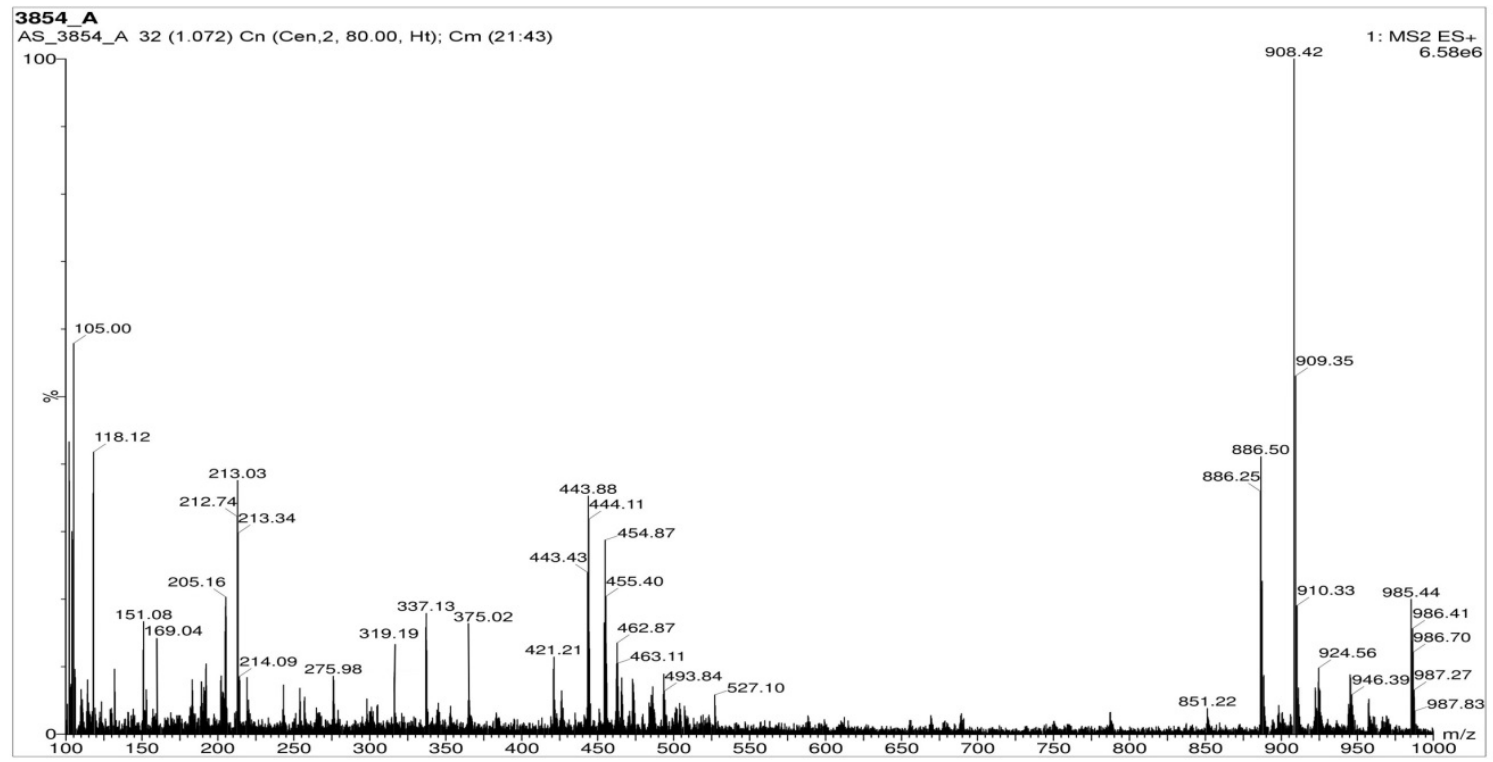

(B)

3855_B

100

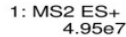

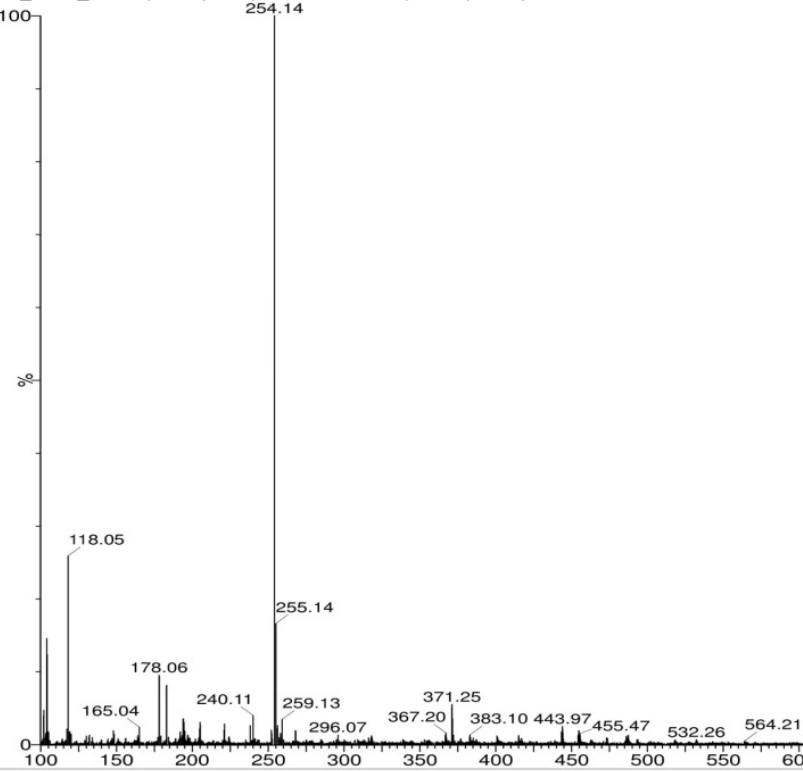

886.34

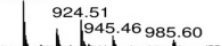

Figure 4. LC MS Chromatogram of A) Parmotrema tinctorum B) Pseudocephallaria aurata extracts 
(A)

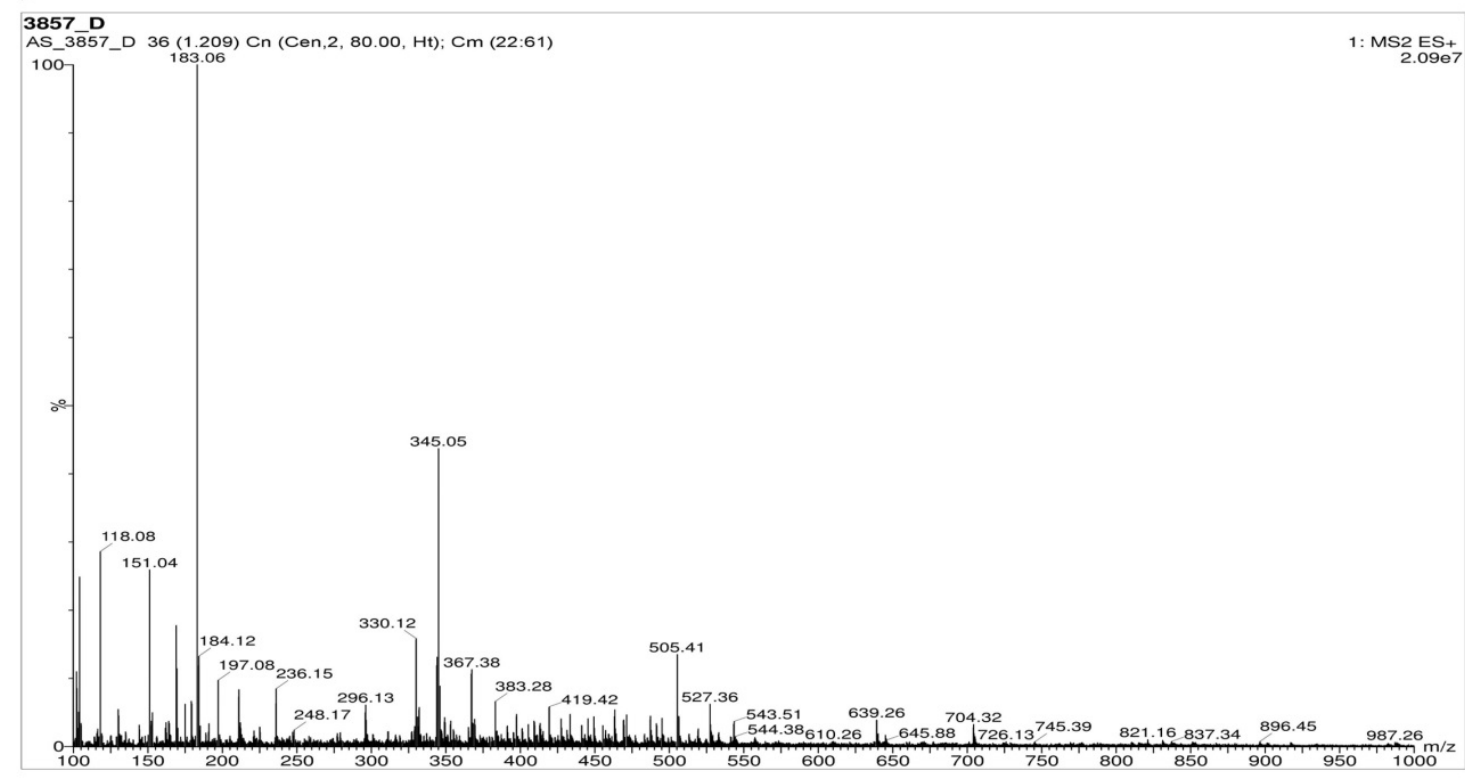

(B)

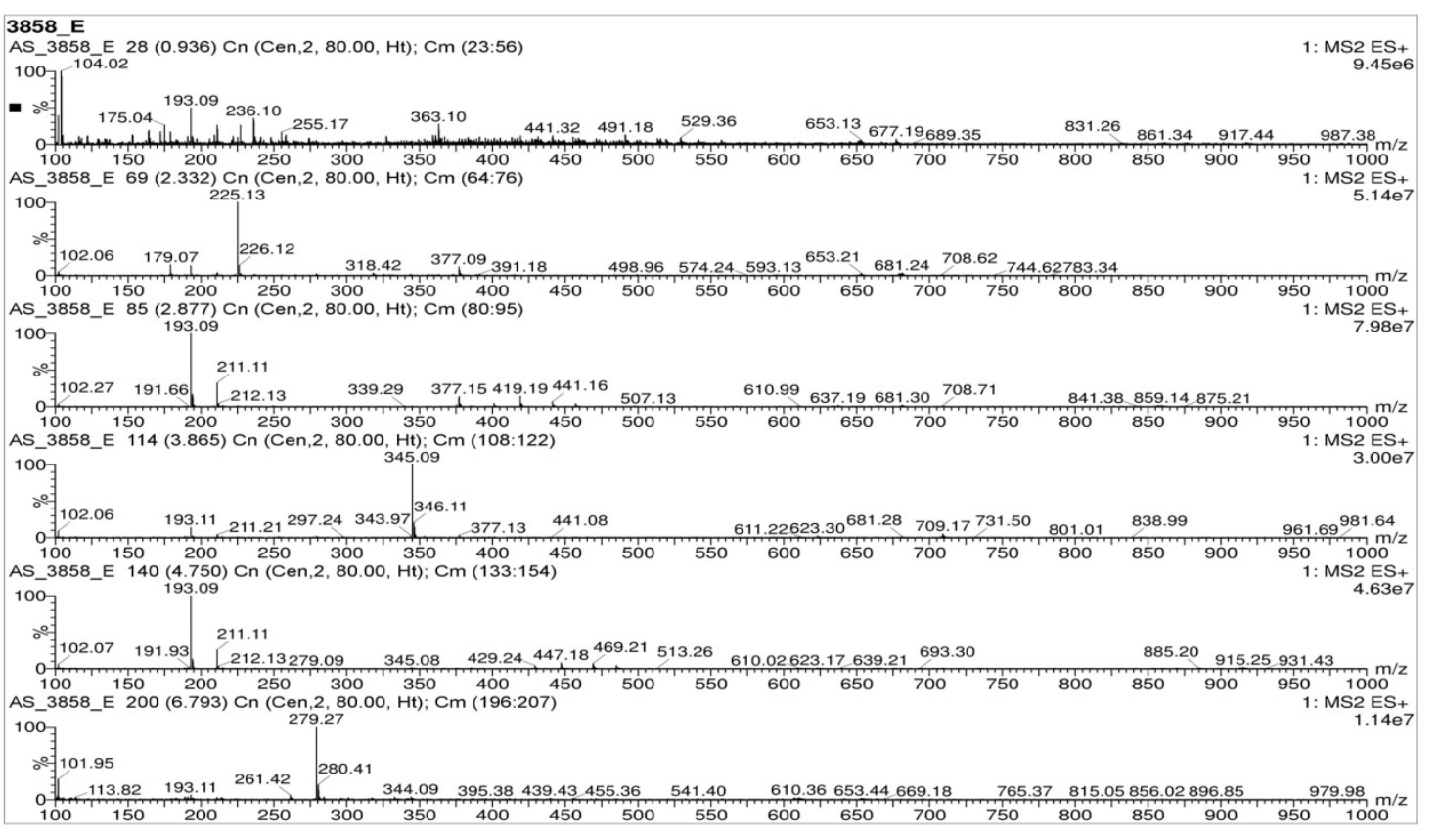

Figure 5. LC MS Chromatogram of A) Ramalina taitensis B) Usnea bismolliuscula extracts

\section{Conclusion}

The present research concluded that the extracts of Parmotrema tinctorum, Pseudocyphellaria aurata, Ramalina taitensis, Usnea bismolliuscula exhibited a variety of phytochemical constituents in solvent extracts. The moderate antioxidant activities of methanol extract depicted the possible application of these lichens in pharmacology. These can be a promising alternative to synthetic antioxidants. Additionally, it is suggested that the lichen substances such as atranorin, sekikaic acid, usnic acid detected in solvent extracts using LC/MS are responsible for radical scavenging activity. Further animal studies are underway to assess the cytoxicity effects of these lichen extracts.

\section{Acknowledgement}

Authors express their gratitude to Dr. A. Rajendran, Professor and Head, Department of Botany, Bharathiar University, Coimbatore, Tamil Nadu, India for providing excellent help throughout this research work. The authors wish to acknowledge the UGC-SAP and DST- FIST, Government of India for their funding towards this study.

\section{Conflict of interest}

The authors have no conflict of interest. 


\section{References}

Abdel-Mawgoud M, Khedr FG, Mohammed EI. 2019. Phenolic Compounds, Antioxidant and Antibacterial Activities of Rhus flexicaulis Baker. Jordan J Biol Sci, 12:17-21.

AOAC AA of OA. 1990. Official methods of analysis15th ed. Method 991.43. Association of Official Analytical Chemists, Arlington, VA, USA

Awasthi DD. 2007. Compendium of the Macrolichens from India, Nepal and Sri Lanka. Bishen Singh Mahendra Pal Singh, Dehradun, India.

Aydin S, Kinalioğlu K, Sökmen BB. 2018. Antioxidant, antiurease and anti-elastase activities of Usnea longissima Ach. Bangladesh J Bot, 47:429-435.

Behera BC, Mangesh V. Morey, Subhash B. Gaikwad. 2016. Anti-lipoxygenase, Radical Scavenging and Antimicrobial Activities of Lichen Species of Genus Heterodermia (Physciaceae). Bot Pacifica J Plant Sci Conserv, 5:79-85.

Biney EE, Nkoom M, Darkwah WK, Puplampu JB. 2020. Highperformance liquid chromatography analysis and antioxidant activities of extract of Azadirachta indica (Neem) leaves. Pharmacogn Res, 12:29.

Chowdhery HJ. 2014. Studies on the Subfamily Apostasioideae (Orchidaceae) in India. Nelumbo, 56:1-13.

Dandapat M and Paul S. 2019. Secondary metabolites from lichen Usnea longissima and its pharmacological relevance. Pharmacogn Res, 11:103.

Gaafar AA, Asker MS, MA A, Salama ZA. 2019. The Effectiveness of the Functional Components of Grape (Vitis vinifera) Pomace as Antioxidant, Antimicrobial, and Antiviral Agents. Jordan J Biol Sci, 12:625-635.

Ganesan A, Purushothaman D, Muralitharan U, Subbaiyan R. 2017. Metabolite profiling and in vitro assessment of antimicrobial and antioxidant activities of lichen Ramalina inflata. Int Res J Pharm, 7:132-138.

Ganesan A, Thangapandian M, Ponnusamy P, Sundararaj JP, Nayaka S. 2015. Antioxidant and antibacterial activity of parmeliod lichens from Shevaroy hills of Eastern Ghats, India. Int J Pharm Tech Res, 8:13-23.

Hu Q, Liu J, Li J, Liu H, Dong N, Geng Y, Lu Y, Wang Y. 2020. Phenolic composition and nutritional attributes of diaphragma juglandis fructus and shell of walnut (Juglans regia L.). Food Sci Biotechnol, 29:187-196.

Jäger H-J, Weigel H-J. 1978. Amino acid metabolism in lichens. Bryologist, 107-113.

Joubert JJ, Steyn PL, Britz TJ, Wessels DCJ. 1982. Chemical composition of some lichen species occurring in the Namib Desert, South West Africa. Dinteria, 16:33-43.

Kazazic M, Djapo M, Ademovic E. 2016. Antioxidant activity of water extracts of some medicinal plants from Herzegovina region. Int J Pure App Biosci, 4:85-90.

Kalidoss. R, Merlin. J, Charumathy. M, Surekha. S, Arun Prasath. K, Mariraj. M, Shenbagam. M, Rajaprabu. N, and Ponmurugan. P 2019.Lichen collections from Nilgiris of Western Ghats in Tamil Nadu and screening for antimicrobial, antioxidant efficacy of some selected species.Pramana research journal. 9(6): 1364-1386.

Kekuda TRP, Vinayaka KS, Swathi D, Suchitha Y, Venugopal TM, Mallikarjun N. 2011. Mineral Composition, Total Phenol Content and Antioxidant Activity of a Macrolichen Everniastrum cirrhatum (Fr.) Hale (Parmeliaceae). E-J Chem, 8:1886-1894.

Kirkpatrick RC. 1996. Ecology and behavior of the yunnan SnubNosed langur (Rhinopithecus bieti, Colobinae)[Ph. D. dissertation]. University of California.
Kosanić M, Ranković B. 2010. Screening of antimicrobial activity of some lichen species in vitro. Kragujevac J Sci, 32:65-72.

Kosanic M, Rankovic B, Stanojkovic T, Vasiljevic P, Manojlovic N. 2014. Biological activities and chemical composition of lichens from Serbia. EXCLI j, 13:1226.

Ladipo MK, Doherty VF, Kanife UC. 2011. Heavy metal analysis and phytochemical screening of two indigenous species (Zingiber officinale and Centrosema pubescens) from Nigeria. Int J Curr Res, 33:95-99.

Liu Y, Xue D, Li W, Li C, Wan B. 2020. A simple method for the precise determination of multi-elements in pyrite and magnetite by ICP-MS and ICP-OES with matrix removal. Microchem $J$, 158:105221.

Lowry OH, Rosebrough NJ. 1951. AL farr and RJ Randall. J biol Chem, 193:6.

Makawy AI, Ibrahim FM, Abdel-Aziem SH. 2019. Assessment of Satureja montana L. and Mentha piperita L. Antioxidant Activity, Cytotoxicity and Pattern of Apoptotic Gene Expression in Hepatoma Cells. Jordan J Biol Sci, 12:251-258.

Manojlovic NT, Vasiljevic PJ, Maskovic PZ, Juskovic M, Bogdanovic-Dusanovic G. 2012. Chemical Composition, Antioxidant, and Antimicrobial Activities of Lichen Umbilicaria cylindrica (L.) Delise (Umbilicariaceae). Evid Based Complement Alternat Med, https://doi.org/10.1155/2012/452431.

Mohapatra D, Patel AS, Kar A, Deshpande SS, Tripathi MK. 2019. Effect of different processing conditions on proximate composition, anti-oxidants, anti-nutrients and amino acid profile of grain sorghum. Food Chem, 271:129-135.

Musharraf SG, Kanwal N, Thadhani VM, Choudhary MI. 2015. Rapid identification of lichen compounds based on the structurefragmentation relationship using ESI-MS/MS analysis. Anal Methods, 7:6066-6076.

Ng Z, Koick Y, Yong P. 2020a. Comparative analyses on radical scavenging and cytotoxic activity of phenolic and flavonoid content from selected medicinal plants. Nat Prod Res, 1-6.

Ng ZX, Chua KH, Kuppusamy UR. 2014. Proteomic analysis of heat treated bitter gourd (Momordica charantia L. var. Hong Kong Green) using 2D-DIGE. Food Chem, 148:155-161.

Ng ZX, Kuppusamy UR, Ng ZX, Kuppusamy UR. 2019. Effects of different heat treatments on the antioxidant activity and ascorbic acid content of bitter melon, Momordica charantia. Braz J Food Technol, 22 doi:10.1590/1981-6723.28318

Ng ZX, Rosman NF. 2019. In vitro digestion and domestic cooking improved the total antioxidant activity and carbohydratedigestive enzymes inhibitory potential of selected edible mushrooms. J Food Sci Technol, 56:865-877.

Ng ZX, Samsuri SN, Yong PH. 2020b. The antioxidant index and chemometric analysis of tannin, flavonoid, and total phenolic extracted from medicinal plant foods with the solvents of different polarities. J Food Process Preserv, e14680.

$\mathrm{Ng}$ ZX, See AN. 2019. Effect of in vitro digestion on the total polyphenol and flavonoid, antioxidant activity and carbohydrate hydrolyzing enzymes inhibitory potential of selected functional plant-based foods. J Food Process Preserv, 43:e13903.

Ng ZX, Yong PH, Lim SY. 2020c. Customized drying treatments increased the extraction of phytochemicals and antioxidant activity from economically viable medicinal plants. Ind Crops Prod, 155:112815.

Nguyen TTH, Dinh MH, Chi HT, Wang S-L, Nguyen Q, Tran TD, Nguyen AD. 2019. Antioxidant and cytotoxic activity of lichens collected from Bidoup Nui Ba National Park, Vietnam. Res Chem Intermed, 45:33-49. 
Orange A, James PW, White FJ. 2001. Microchemical methods for the identification of lichens. Twayne Publishers, USA.

Rahman E, Momin A, Zhao L, Guo X, Xu D, Zhou F, Ji B. 2018. Bioactive, nutritional composition, heavy metal and pesticide residue of four Chinese jujube cultivars. Food Sci Biotechnol, 27:323-331.

Raj PS, Prathapan A, Sebastian J, Antony AK, Riya MP, Rani MRP, Biju H, Priya S, Raghu KG. 2014. Parmotrema tinctorum exhibits antioxidant, antiglycation and inhibitory activities against aldose reductase and carbohydrate digestive enzymes: an in vitro study. Nat Prod Res, 28:1480-1484.

Rajeswari N, Mesta AR, Kanivebagilu VS, Babu HR. 2019. Medicinal importance of Usneoid lichens in Western Ghats, Southern India. Plant Arch, 19:2540-2542.

Rice-evans CA, Miller NJ, Bolwell PG, Bramley PM, Pridham JB. 1995. The Relative Antioxidant Activities of Plant-Derived Polyphenolic Flavonoids. Free Radic Res, 22:375-383.

Ristić S, Ranković B, Kosanić M, Stanojković T, Stamenković S, Vasiljević P, Manojlović I, Manojlović N. 2016. Phytochemical study and antioxidant, antimicrobial and anticancer activities of Melanelia subaurifera and Melanelia fuliginosa lichens. J Food Sci Technol, 53:2804-2816.

Robbins CT. 1987. Digestibility of an arboreal lichen by mule deer. Rangel Ecol Manag Range Manag Arch, 40:491-492.

Sarker S, Latif Z, Gray A. 2006. Natural product isolation: an overview. Methods in Biotechnology https://pubs.acs.org/doi/10.1021/np078142v

Sedjati S, Pringgenies D, Fajri M. 2020. Determination of the Pigment Content and Antioxidant Activity of the Marine Microalga Tetraselmis suecica. Jordan J Biol Sci, 13:55-58.

Shelukheeva MG, Nikolaeva IG. 2015. Amino Acids from Lichens of the Genera Cladina and Cladonia. Chem Nat Compd, 51:397-398.
Shrestha G, St. Clair LL. 2013. Lichens: a promising source of antibiotic and anticancer drugs. Phytochem Rev, 12:229-244.

Singleton VL, Orthofer R, Lamuela-Raventós RM. 1999. Analysis of total phenols and other oxidation substrates and antioxidants by means of folin-ciocalteu reagent. Methods in Enzymology. Academic Press. 299: 152-178.

Thangaraj P. 2016. Pharmacological assays of plant-based natural products. Springer.

Tomović J, Rančić A, Vasiljević P, Mašković P, Živanović S, Manojlović N, Sovrlić M. 2016. Antioxidant activity of lichen Cetraria aculeata. Prax medica, 45:93-99.

Upreti DK, Divakar PK, Nayaka S. 2005. Commercial and ethnic use of lichens in India. Eco Bot, 59:269.

Vinayaka KS, Kekuda TRP, Kumar K a. R, Pavithra GM, Junaid S, Rakesh KN, Dileep N. 2013. Analysis of mineral elements of the lichen Usnea pictoides G. Awasthi by ICP-OES. Int J Chem Sci, 11:1589-1594.

Vinayaka KS, Kumar SP, Mallikarjun N, Kekuda PTR. 2010. Studies on insecticidal activity and nutritive composition of a macrolichen Parmotrema pseudotinctorum (des. Abb.) Hale (Parmeliaceae). Drug Invent Today, 2:102-105.

Zengin G, Sarikurkcu C, Gunes E, Uysal A, Ceylan R, Uysal S, Gungor H, Aktumsek A. 2015. Two Ganoderma species: profiling of phenolic compounds by HPLC-DAD, antioxidant, antimicrobial and inhibitory activities on key enzymes linked to diabetes mellitus, Alzheimer's disease and skin disorders. Food Funct, 6:2794-2802.

Zhang L, Wang S, Yang R, Mao J, Jiang J, Wang X, Zhang W, Zhang Q, Li P. 2019. Simultaneous determination of tocopherols, carotenoids and phytosterols in edible vegetable oil by ultrasoundassisted saponification, LLE and LC-MS/MS. Food Chem, 289:313-319. 